\title{
ARTICLE Novel-smoothened inhibitors for therapeutic targeting of naïve and drug-resistant hedgehog pathway-driven cancers
}

\author{
Qing-rou $\mathrm{Li}^{1}$, Hui Zhao ${ }^{1}$, Xue-sai Zhang ${ }^{1}$, Henk Lang ${ }^{2}$ and Ker Yu ${ }^{1}$
}

The G protein-coupled receptor (GPCR) smoothened (SMO) is a key signaling component of the sonic hedgehog (Hh) pathway and a clinically validated target for cancer treatment. The FDA-approved SMO inhibitors GDC-0449/Vismodegib and LDE225/Sonidegib demonstrated clinical antitumor efficacy. Nevertheless, relatively high percentage of treated patients would eventually develop acquired cross resistance to both drugs. Here, based on published structure and activity of GDC-0449 inhibitor class, we replaced its amide core with benzimidazole which retained bulk of the SMO-targeting activity as measured in our Hh/SMO/Gli1-reporter system. Synthesis and screening of multiple series of benzimidazole derivatives identified $\mathrm{HH}-1, \mathrm{HH}-13$, and $\mathrm{HH}-20$ with potent target suppression $\left(\mathrm{IC}_{50}:<0.1 \mu \mathrm{mol} / \mathrm{L}\right)$ in the reporter assays. In NIH3T3 cells stimulated with a secreted $\mathrm{Hh}(\mathrm{SHH})$, these inhibitors dose dependently reduced mRNA and protein expression of the endogenous pathway components PTCH-1, Gli1, and cyclin D1 resulting in growth inhibition via $\mathrm{G}_{0} / \mathrm{G}_{1}$ arrest. Mechanistically, the SMO-targeted growth inhibition involved downregulation of mTOR signaling inputs and readouts consistent with diminished mTORC1/mTORC2 functions and apoptosis. In mice, as with GDC-0449, orally administered $\mathrm{HH}$ inhibitors blocked paracrine activation of stromal Hh pathway in Calu- 6 tumor microenvironment and attenuated growth of $\mathrm{PTCH}^{+/-} / \mathrm{P} 53^{-/-}$medulloblastoma allograft tumors. Furthermore, $\mathrm{HH}-13$ and $\mathrm{HH}-20$ potently targeted the drug-resistant smoothened SMO-D473H (IC 50 : $<0.2 \mu \mathrm{mol} / \mathrm{L})$ compared to the poor inhibition by GDC-0449 $\left(\mathrm{IC}_{50}:>60 \mu \mathrm{mol} / \mathrm{L}\right)$. These results identify $\mathrm{HH}-13$ and $\mathrm{HH}-20$ as potent inhibitors capable of targeting naïve and drug-resistant $\mathrm{Hh} / \mathrm{SMO}$-driven cancers. The current leads may be optimized to improve pharmaceutical property for potential development of new therapy for treatment of Hh pathway-driven cancers.

Keywords: hedgehog; smoothened inhibitor; paracrine; acquired drug resistance

Acta Pharmacologica Sinica (2019) 40:257-267; https://doi.org/10.1038/s41401-018-0019-5

\section{INTRODUCTION}

The sonic hedgehog $(\mathrm{Hh})$ signaling pathway is essential for embryonic development and organ formation [1]. Upon completing embryogenesis, the Hh pathway generally goes silent while remains active in certain circumstances such as hair follicle maintenance and tissue repair [2]. The canonical Hh signaling is initiated by the $\mathrm{Hh}$ ligand binding to the pathway suppressor PTCH-1. This action rapidly stimulates the key $G$ protein-coupled receptor (GPCR) smoothened (SMO) leading to activation of Gli transcription factors and pathway biological function [3].

Aberrant $\mathrm{Hh} / \mathrm{SMO} / \mathrm{Gli} 1$ signaling pathway is linked to pathogenesis of numerous human cancers including advanced basal-cell carcinoma $(\mathrm{BCC})$, medulloblastoma (MB), and other solid tumors $[4,5]$. Studies also identified at least three mechanisms of $\mathrm{Hh}$ pathway activation in tumorigenesis, including the autocrine ligand-dependent, paracrine ligand-dependent, [6] and ligandindependent activation $[3,5,7]$. In the ligand-independent setting, tumors were frequently found to possess the genetic loss of PTCH1 , resulting in constitutive over-activation of SMO [3]. Employing gene depletion technique or small molecule inhibitors, targeting Hh pathway led to antitumor efficacy in preclinical models of $B B C$ and $M B$ both in vitro and in vivo [8]. These earlier findings draw increasing attention to $\mathrm{Hh} / \mathrm{SMO}$ pathway in cancer biology and therapy development. Thus far, two SMO inhibitors Vismodegib
(GDC-0449) and Sonidegib (LDE225) have received FDA approval for cancer treatment. In clinical trials, GDC-0449 and LDE225 were used as single agent therapy in BCC and MB patients and achieved impressive clinical response in overall disease control [9-11].

Acquired drug resistance is a major and evolving challenge in targeted cancer therapy, including those with the approved SMO inhibitors $[12,13]$. Clinical experience indicated that GDC-0449 and LDE225 could confront a cross resistance [14]. To address this issue, resistance mechanisms are under intense investigation. Employing genomic analysis of GDC-0449-resistant tumors, several SMO gene mutations have been discovered [15]. It particular, a recurring mechanism involves the SMO-D473H mutation, which blocks GDC-0449 or LDE225 from efficient binding to the mutant SMO protein. In a study, nearly $40 \%$ BCC patients who acquired resistance were shown to contain SMO mutations and $17 \%$ patients carry the SMO-D473H molecular type [16]. More recently, new generation SMO inhibitors such as TAK441, LEQ-506, and IPI-926 have entered clinical studies [17-19]. These latest agents could overcome mutant SMO activity in the preclinical setting and their clinical performances are eagerly awaited.

In this study, we aimed to design and screen a series of new SMO inhibitors. We show that several compounds not only

\footnotetext{
${ }^{1}$ Department of Pharmacology, Fudan University School of Pharmacy, 201203 Shanghai, China and ${ }^{2}$ Sundia MediTech, 050031 Shijiazhuang, China Correspondence: Ker Yu (keryu@fudan.edu.cn)

These authors contributed equally: Qing-rou Li, Hui Zhao.
}

Received: 20 September 2017 Revised: 31 January 2018 Accepted: 11 February 2018

Published online: 18 May 2018 
displayed potent suppression of the Hh pathway function but also are able to overcome the drug resistance caused by SMO-D473H.

\section{MATERIALS AND METHODS}

Chemicals and cell culture

The current $\mathrm{HH}$ series of compounds were synthesized as described [20, 21]. GDC-0449 was purchased from BiochemPartner (Shanghai). Smoothened agonist (SAG) was purchased from Sant Cruz Biotechnology. Inhibitors were dissolved in DMSO as $20 \mathrm{mmol} / \mathrm{L}$ stock solution and were freshly diluted before assays. HEK293T, NIH3T3, and Calu-6 cell lines were purchased from American Type Culture Collection (ATCC) and were cultured as recommended.

\section{SMO-D473H mutagenesis}

p-CMV6-Smo-D473H point mutation was established with standard site-directed mutagenesis technique. Primers were as follows: F: 5'-TGAAGAAGTGGTAGAAGTGGCAGCTGAAGGTAAT-3'; R: 5'-CACTTCTACCACTTCTTCAACCAGGCTGAGT-3'.

Secreted hedgehog $(\mathrm{SHH})$ condition medium (SHH-CM) 293 T cells were plated $3 \times 10^{6}$ cells per well in $55 \mathrm{~cm}^{2}$ dish. The next day, cells were transfected with pcDNA3.1 ShhN construct encoding the $\mathrm{N}$-terminus secreted $\mathrm{Hh}$ fragment ( $\mathrm{SHH}$, Addgene) using Lipofectamine 2000 (Invitrogen). After $24 \mathrm{~h}$, medium was replaced with DMEM containing $2 \%$ FBS. The SHH-CM was collected at 48 and $72 \mathrm{~h}$, pooled and then centrifuged at $1000 \mathrm{rpm}$ for $10 \mathrm{~min}$. The supernatant was stored at $4{ }^{\circ} \mathrm{C}$ until use within a week.

\section{Gli1-luciferase reporter assay}

$\mathrm{NIH} 3 \mathrm{~T} 3$ cells were plated in 96 -well plate at $5 \times 10^{3}$ cells per well for overnight. Cells were transfected with $180 \mathrm{ng} 8 \times 3^{\prime}$ Gli-BSdelta51-Lucll (Rlkagaku KENkyusho/Institute of Physical and Chemical Research) and 20 ng TK-Renilla using Lipofectamine 2000. After $6 \mathrm{~h}$, medium was refreshed to $10 \%$ new-born calf serum (NBCS) in DMEM for $24 \mathrm{~h}$. On the day of inhibitor assay, cells were fed with medium containing $0.5 \%$ NBCS for $1 \mathrm{~h}$, then stimulated with $100 \mathrm{ng} / \mathrm{mL}$ SAG or $50 \mu \mathrm{L}$ SHH-CM without or with various testing inhibitor compounds. Forty-eight hours later, cells were lysed and tested for luciferase activity with Dual-Luciferase Reporter Assay Kit (YPHbio, Beijing). For GDC-0449-resistant assay system, 293T cells were plated in 96 -well plate, $5 \times 10^{3}$ per well. The next day, cells were transfected with $100 \mathrm{ng} 8 \times 3^{\prime}$ Gli-BSdelta51-Lucll and $100 \mathrm{ng}$ p-CMV6-SMO-WT or p-CMV6-SMO$\mathrm{D} 473 \mathrm{H}$ plasmid DNA for $24 \mathrm{~h}$, treated with various inhibitors for $48 \mathrm{~h}$, followed by luciferase activity assay performed as described above.

\section{RT-PCR assay of gene expression}

Cells or tumors were harvested and extracted total RNA according to SuperfecTRI total RNA Isolation Reagent (Pufei, Shanghai). Reverse transcription of mRNA into cDNA was performed with RevertAid First Strand cDNA Synthesis Kit (Fermentas), subjected to PCR with FastStart Universal SYRB Green Master (Rox) Kit (Roche) in iQ5 Cycler (Bio-Rad). PCR primers included mouse Gli1, F: 5'-GCAGTGGGTAACATGAGTGTCT-3', R: 5'-AGGCACTAGAGTTGAGGAATTGT-3'; mouse PTCH-1, F: 5'-CTCTGGAGCAGATTTC CAAGG-3', R: 5'-TGCCGCAGTTCTITTGAATG-3'; mouse CycinD1, F: 5'-GTGCGTGCAGAAGGAGATTG-3', R: 5'-AGGTTCAGGCCTTGCATC3'; mouse RPL19, F: 5'-AGAAGGTGACCTGGATGAGA-3', R: 5'TGATACATATGGCGGTCAATCT-3'; human GAPDH, F: 5'-TTCACCACCATGGAGAAGGC-3', R: 5'-GGCATGGACTGTGGTCATGA-3'; human SMO, F: 5'- ACCTATGCCTGGCACACTTC-3', R: 5'- GTGAGGACAAAGGGGAGTGA-3'. Relative gene expression was analyzed and normalized to RPL19 (mouse genes) or GAPDH (human genes).
Cell proliferation and cell cycle analysis

Cell proliferation was assayed with the indicated treatments for 3 days using MTS reagent (Promega) as previously described [22]. For cell cycle profiling, cells were treated as indicated for $24 \mathrm{~h}$ and analyzed in a Becton Dickinson FACS Calibur flow cytometer by collecting 10,000 events.

\section{Apoptosis assay}

293T cells were transiently transfected with p-CMV6-SMO-WT for $24 \mathrm{~h}$, treated with inhibitors for $48 \mathrm{~h}$. The cells were harvested, stained with Annexin V-FITC/PI staining kit (KeyGEN BioTECH, Cat\# KGA108) and analyzed by FACS.

Calu- 6 human lung tumor xenografts

Animal studies were performed under protocols approved by Institutional Animal Care and Use Committee (IACUC) of Fudan University. Balb/c female nude mice (Shanghai Sippr-BK laboratory animal Co. Ltd.) between 6 and 8 weeks of age were subcutaneously injected $4 \times 10^{6}$ Calu- 6 cells in a Matrigel (BD Biosciences) /DMEM mixture. When tumor size reached $\sim 400 \mathrm{~mm}^{3}$, mice were treated twice a day (bid) with vehicle (20\% HP- $\beta-C D)$ or $75 \mathrm{mg} / \mathrm{kg}$ GDC-0449, $\mathrm{HH}-1, \mathrm{HH}-13$, and $\mathrm{HH}-20$ by oral gavage. Mice were killed after five treatments. Tumors were collected and analyzed for mouse stromal cell mRNA level through RT-PCR.

$\mathrm{PTCH}^{+/-} / \mathrm{P}^{2} 3^{-/-}$mouse medulloblastoma (MB) model C57BL/6J PTCH1 tmlMps/J (PTCH ${ }^{+/-}$) was purchased from Jackson Laboratory, C57BL/6J B6.129S2-Trp53tmITyj/JNju (P53 ${ }^{-/-}$) was purchased from Model Animal Research Center of Nanjing University. $\mathrm{PTCH}^{+/-} / \mathrm{P} 53^{-/-}$mouse $\mathrm{MB}$ model on a $\mathrm{C} 57 \mathrm{BL} / 6$ background was generated as previously described [23]. Mice with spontaneous MB tumors were sacrificed. Tumors were dissected from cerebellum and then subcutaneously implanted into Balb/c female nude mice (6-8 week) (P1 tumors). The grafted tumors were allowed to grow to $300-500 \mathrm{~mm}^{3}$ before harvested and serially passaged (P2 and P3 tumors). For efficacy studies, tumor fragments were implanted into flank of female nude mice. Mice bearing staged tumors $\left(150-200 \mathrm{~mm}^{3}\right.$ in size) were randomized into groups $(n=8)$, treated orally with vehicle or the indicated inhibitors via a twice daily (bid) regimen. Tumor growth was monitored with caliper every 2 days. Tumor volume was calculated as $V\left(\mathrm{~mm}^{3}\right)=L \times W \times W / 2$. Tumors were collected at the end of study.

\section{Immunoblotting}

For standard assay of inhibitor effects on cellular biomarker expression, cells were plated at predetermined density in 6-well culture plates for overnight, treated with $\mathrm{SHH}-\mathrm{CM}$ without or with inhibitors for the indicated doses and time. Cells were lysed with NuPAGE-LDS lysis buffer (Invitrogen) and immunoblotted with antibodies including Gli1 (Santa Cruz); PTCH-1, cyclin D1, P-TSC2 (T1462), P-mTOR(S2481), mTOR (Cell Signaling Technology); SMO (Abgent); P-AKT(S473), AKT, P-S6(S235/236), S6 (Abcam-Epitomics); MCL-1 (Affinity); $\beta$-actin, GAPDH (Bioworld). Immunoblotting of in vivo tumors were performed as described previously [22].

Statistical analysis

All numerical data processing and statistical analysis were performed with Microsoft Excel Software; values were expressed as means $\pm \mathrm{SD}$. $P$ values were calculated using unpaired two-tailed Student $t$ test.

\section{RESULTS}

Discovery of benzimidazole derivatives as novel SMO inhibitors To identify novel SMO inhibitors, we first analyzed the published structure and activity information for GDC-0449 and its analogs. 
a

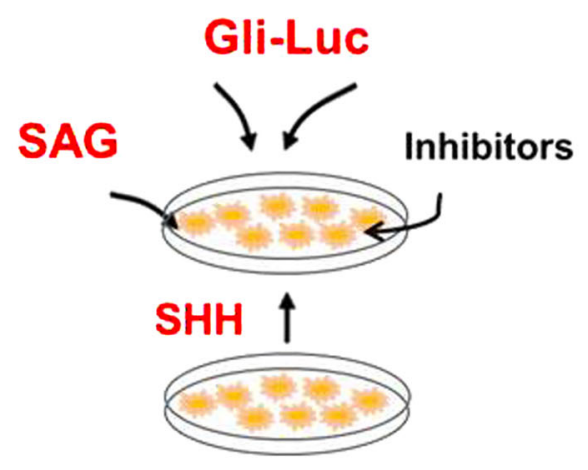

d<smiles>CC(C)(C)CC1CCC(C2CC3CC(O)C(C4CCCC4)CC3C2)CC1C1CCCCC1</smiles><smiles></smiles>

b

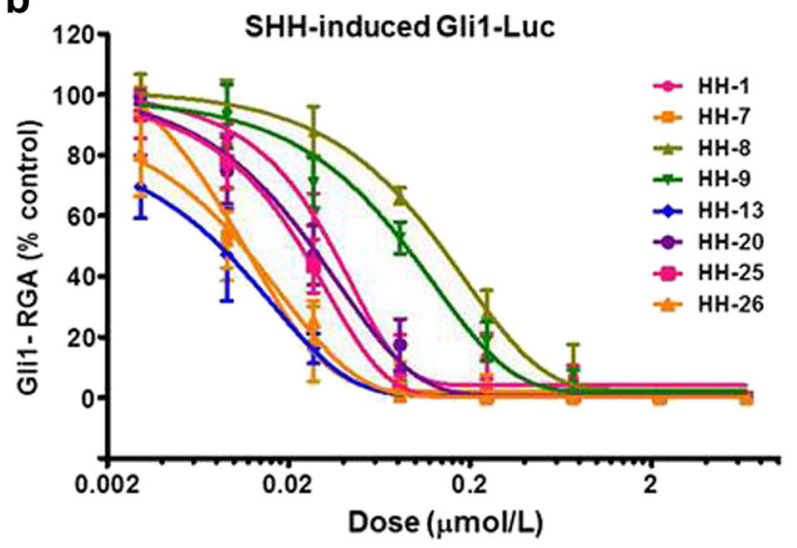

\begin{tabular}{|c|c|}
\hline Inhibitor & $I_{50}$ (nmol/L) \\
\hline HH-1 & $44.71 \pm 11.39$ \\
\hline HH-7 & $12.22 \pm 7.24$ \\
\hline HH-8 & $145.03 \pm 53.08$ \\
\hline HH-9 & $99.36 \pm 18.41$ \\
\hline HH-13 & $6.75 \pm 1.19$ \\
\hline HH-20 & $21.71 \pm 11.04$ \\
\hline HH-25 & $25.71 \pm 7.73$ \\
\hline HH-26 & $11.50 \pm 3.58$ \\
\hline
\end{tabular}

C

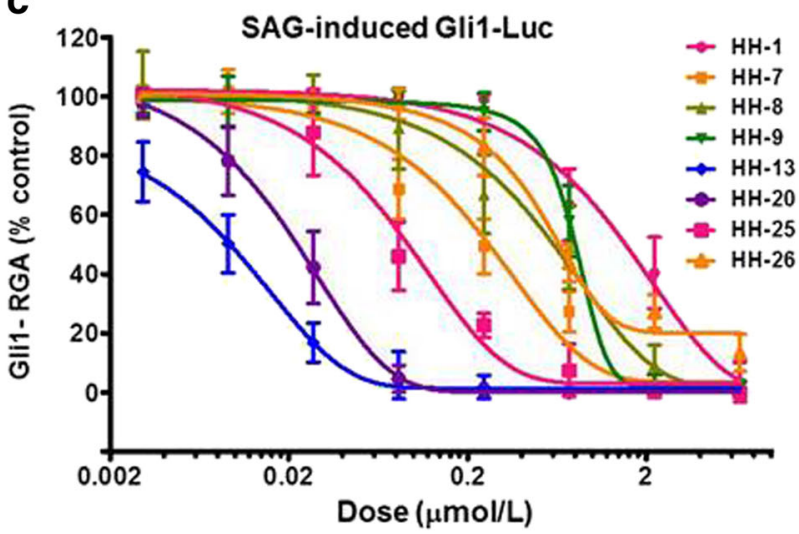

\begin{tabular}{|c|c|}
\hline Inhibitor & $\mathrm{IC}_{50}$ (nmol/L) \\
\hline $\mathrm{HH}-1$ & $1548 \pm 204.4$ \\
\hline $\mathrm{HH}-7$ & $267.37 \pm 72.09$ \\
\hline $\mathrm{HH}-8$ & $593.86 \pm 146.93$ \\
\hline $\mathrm{HH}-9$ & $796.68 \pm 137.02$ \\
\hline $\mathrm{HH}-13$ & $9.28 \pm 2.43$ \\
\hline $\mathrm{HH}-20$ & $28.90 \pm 3.54$ \\
\hline HH-25 & $80.67 \pm 33.61$ \\
\hline HH-26 & $659.62 \pm 100.90$ \\
\hline
\end{tabular}

Fig. 1 Screening of newly designed SMO inhibitor compounds in NIH3T3 cell Gli1 report gene assay . a Gli1-luciferase assay scheme is shown. The assays were performed as described in Method. b, c Dose-response inhibition curves (left) and IC $C_{50}$ values (right) are shown. The cellular $\mathrm{Hh}$ pathway activation was induced with SHH-CM (b) or SAG (c). d Chemical structures of $\mathrm{HH}-1, \mathrm{HH}-13$, and $\mathrm{HH}-20$ are shown

This analysis led to the design and synthesis of multiple series of substituted benzimidazole derivatives $[20,21]$. Antagonists were screened by two versions of cell-based Gli1-reporter assay. The Gli1-luc reporter activity was induced either with a secreted hedgehog-condition medium (SHH-CM) or with a known SMO agonist (SAG) compound (Fig. 1a). In the SHH-induced reporter system, numerous compounds displayed potent antagonist activity with $\mathrm{IC}_{50}$ value range $<200 \mathrm{nmol} / \mathrm{L}$ (Fig. 1b). When screened in the SAG-induced reporter system, while majority of the compounds showed a significantly reduced potency, compounds $\mathrm{HH}-13$ and $\mathrm{HH}-20$ retained potent antagonist activity (Fig. 1c). Specifically, $\mathrm{HH}-13$ and $\mathrm{HH}-20$ elicited respective $\mathrm{IC}_{50}$ values of 6.8 and $21.7 \mathrm{nmol} / \mathrm{L}$ in $\mathrm{SHH}-\mathrm{CM}$ system, and showed 9.3 and $28.9 \mathrm{nmol} / \mathrm{L}$ in SAG system (Fig. 1b, c). Meanwhile, we performed in vivo bioavailability studies and found that the mouse oral exposure ratio for compound $\mathrm{HH}-1$ was significantly higher than other compounds (Figure S1A). These results and additional findings (see below) led us to select $\mathrm{HH}-1, \mathrm{HH}-13$, and $\mathrm{HH}-20$ (Fig. 1d) as hit molecules.

Targeting of the Hh pathway gene transcription In serum-starved NIH3T3 stimulated with SHH-CM, mRNA expression of the Hh pathway genes Gli1, PTCH-1, and cyclin D1 increased by $\sim 60$-fold, 20 -fold, and 2-fold, respectively (Fig. 2a). To test the inhibitory effect on these genes, serum-starved NIH3T3 cells were induced with $\mathrm{SHH}-\mathrm{CM}$ in the presence of inhibitors for $48 \mathrm{~h}$. All three inhibitors dose dependently reduced mRNA levels for Gli1 (Fig. 2b), PTCH-1 (Fig. 2c) with an overall potency order of $\mathrm{HH}-13>\mathrm{HH}-20>\mathrm{HH}-1$. Specifically, both $\mathrm{HH}-13$ and $\mathrm{HH}-20$ inhibited these two genes at doses as low as $0.01-0.05 \mu \mathrm{mol} / \mathrm{L}$, while 
a
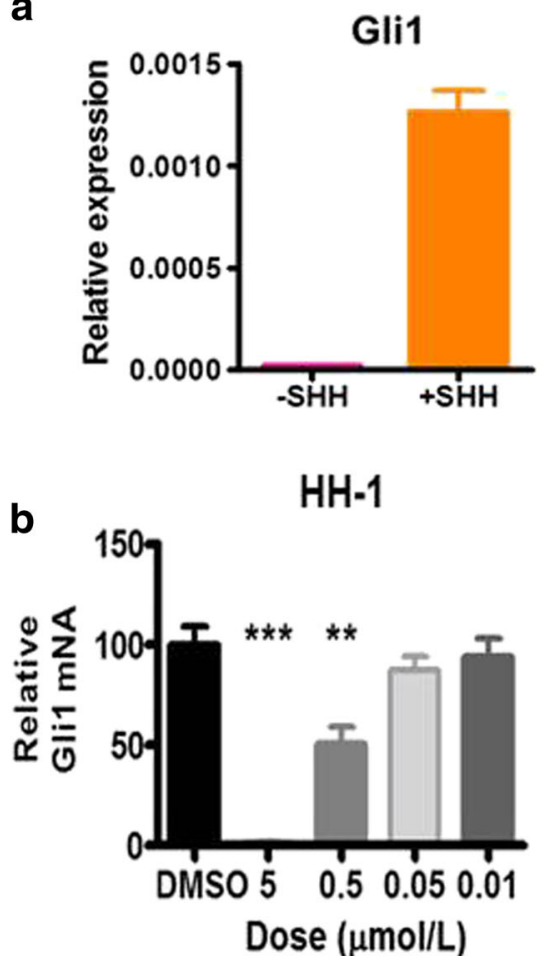

C
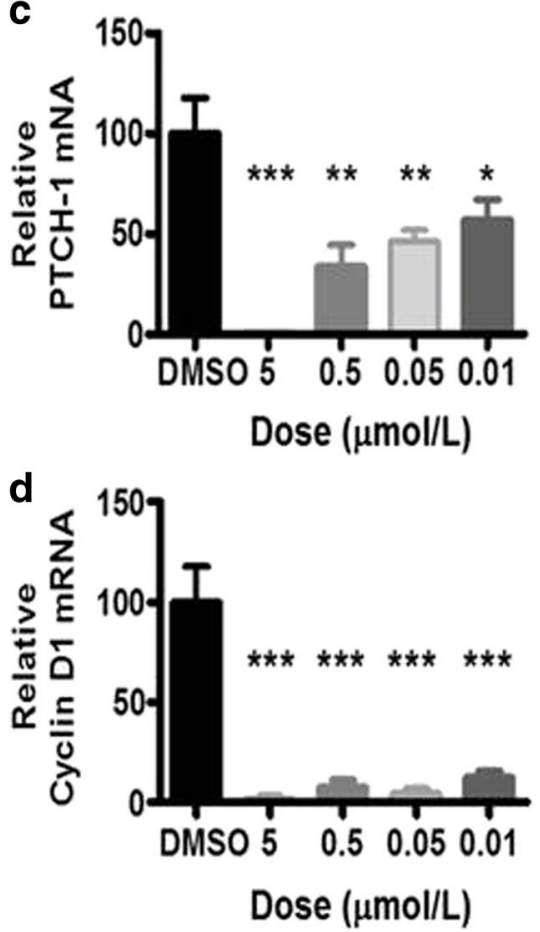

PTCH-1

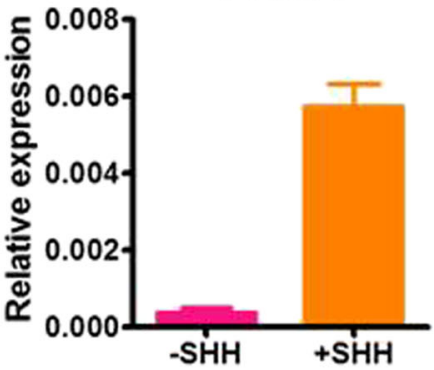

$\mathrm{HH}-13$
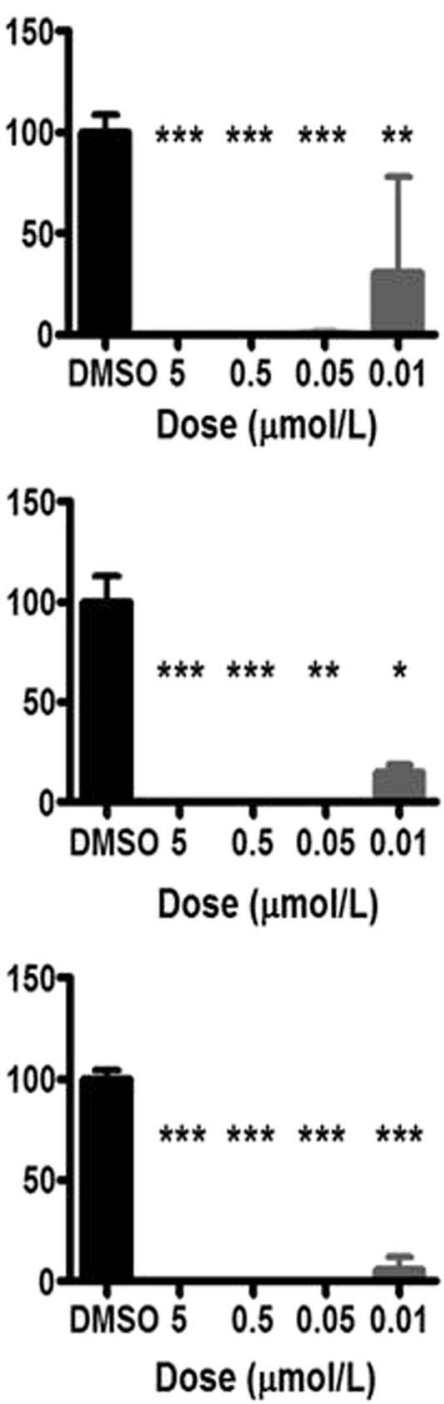

Cyclin D1

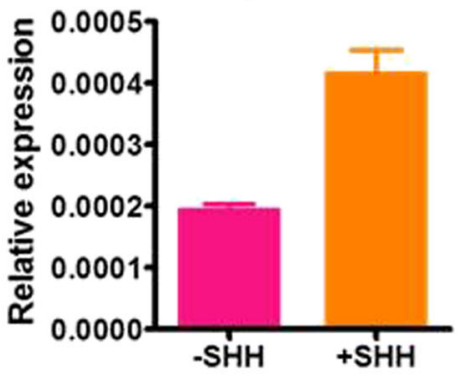

HH-20
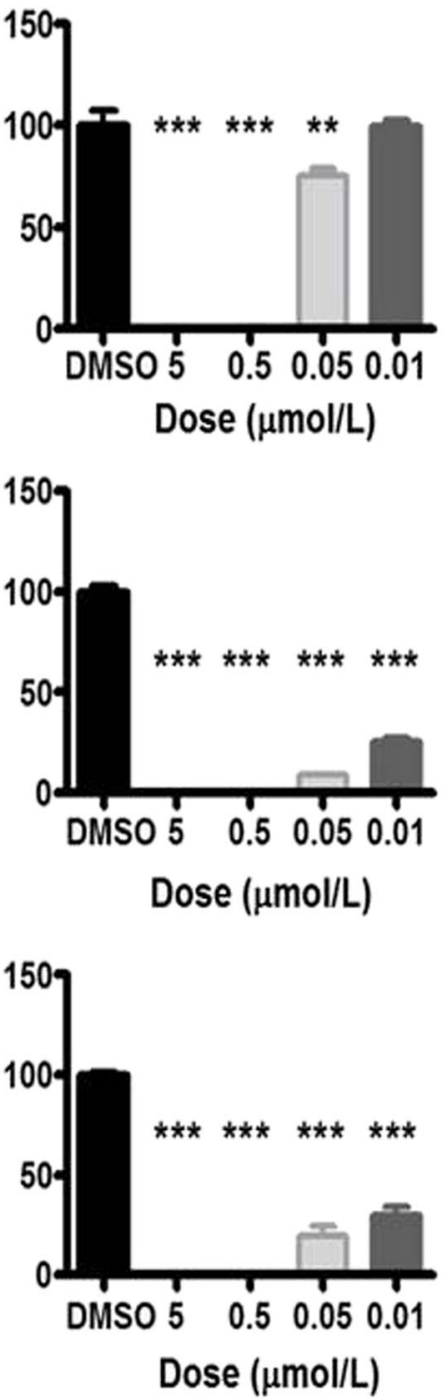

Fig. 2 New SMO inhibitors target the Hh pathway gene expression. a mRNA levels of Gli1, PTCH-1, and cyclin D1 were analyzed after serumstarved NIH3T3 cells were induced with SHH-CM for $48 \mathrm{~h}$ as described in Methods. b-d Serum-starved NIH3T3 cells were similarly induced by $\mathrm{SHH}-\mathrm{CM}$ with vehicle or the indicated inhibitors for $48 \mathrm{~h}$. Cells were analyzed for mRNA levels of Gli1 (b), PTCH-1 (c), and cyclin D1 (d). Relative expression levels are shown. Statistical analysis (treated vs. DMSO control): ${ }^{*} P<0.05 ;{ }^{* *} P<0.01 ;{ }^{* *} P<0.001$

$\mathrm{HH}-1$ showed inhibition at $0.5 \mu \mathrm{mol} / \mathrm{L}$ (Fig. 2b, c). Interestingly, all three inhibitors profoundly inhibited the expression of cyclin D1 even at $0.01-0.05 \mu \mathrm{mol} / \mathrm{L}$ (Fig. $2 \mathrm{~d}$ ). These results demonstrate a dose-dependent inhibition of the endogenous Hh-target gene transcription in response to treatment with $\mathrm{HH}-1, \mathrm{HH}-13$, and $\mathrm{HH}-20$.
Inhibition of Hh ligand-dependent cell growth

We next established an $\mathrm{Hh}$ pathway-dependent growth assay system. Treatment of NIH3T3 cells with SHH-CM led to a sharp increase in cell growth which could be suppressed by GDC-0449 (Fig. 3a). In this assay system, while the vast majority of inhibitors displayed an expected inhibitory activity, $\mathrm{HH}-13$ and $\mathrm{HH}-20$ 
a

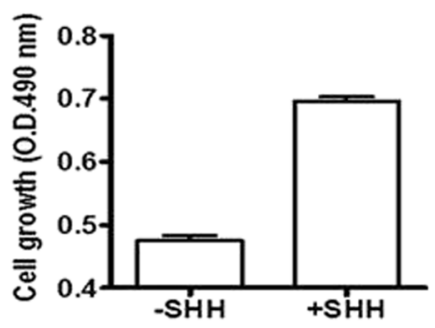

b

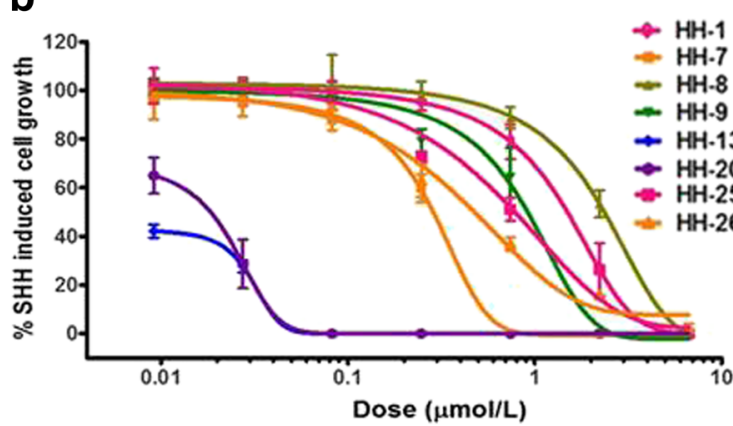

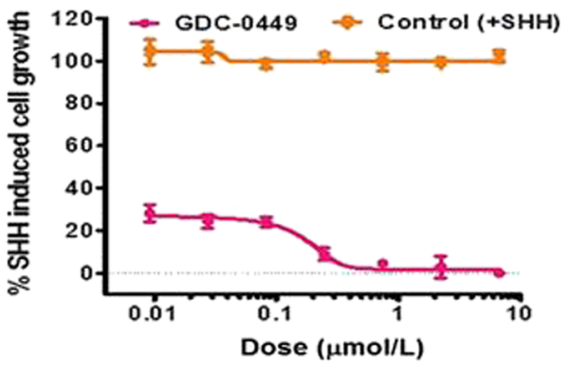

\begin{tabular}{cc}
\hline Inhibitor & $I_{50}(\mathrm{nmol} / \mathrm{L})$ \\
\hline $\mathrm{HH}-1$ & $1563.88 \pm 287.60$ \\
$\mathrm{HH}-7$ & $287.83 \pm 33.99$ \\
$\mathrm{HH}-8$ & $2315.44 \pm 131.98$ \\
$\mathrm{HH}-9$ & $806.34 \pm 17.87$ \\
$\mathrm{HH}-13$ & $<9$ \\
$\mathrm{HH}-20$ & $20.92 \pm 3.75$ \\
$\mathrm{HH}-25$ & $891.54 \pm 128.01$ \\
$\mathrm{HH}-26$ & $473.33 \pm 42.43$ \\
\hline
\end{tabular}

S
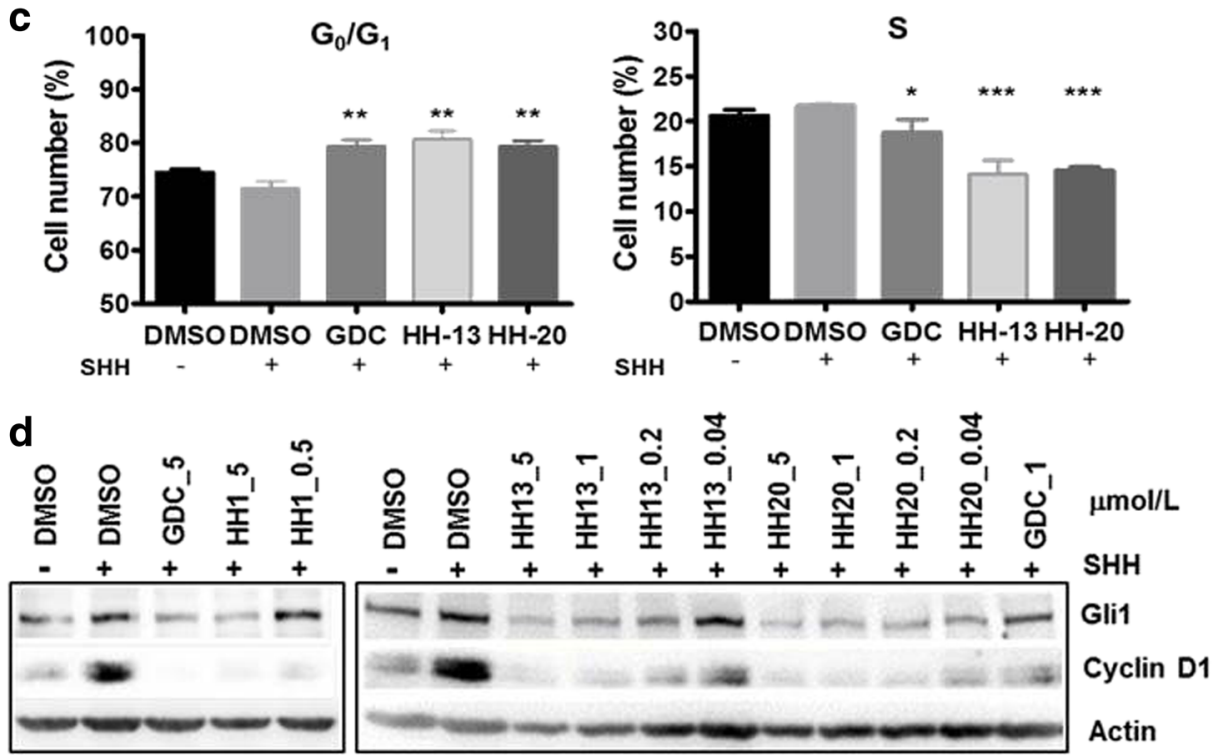

Fig. 3 Targeting of Hh pathway leads to inhibition of cell proliferation. a The SHH-induced NIH3T3 cell proliferation model was established (left panel) and validated with GDC-0449 (right panel). Cells were induced by SHH-CM for $72 \mathrm{~h}$ and measured for cell proliferation as described in Methods. $\mathbf{b}$ Cells as in a were treated with vehicle or the indicated inhibitors for $72 \mathrm{~h}$ followed by proliferation assay using MTS reagent. Growth inhibition dose-response curves are shown (left panel) and $I C_{50}$ values are shown (right panel). c Cells as in a were treated with the indicated inhibitors for $24 \mathrm{~h}$, subjected to cell cycle analysis by FACS. Cell populations in $\mathrm{G}_{0} / \mathrm{G}_{1}$ and $\mathrm{S}$ phase are shown. d Cells as in a were treated with the indicated inhibitors for $48 \mathrm{~h}$. Total cell lysates were collected and subjected to immunoblotting. Statistical analysis (treated vs. DMSO control): ${ }^{*} P<0.05 ;{ }^{* * P}<0.01 ;{ }^{* * *} P<0.001$

showed the most potent and consistent suppression of cell growth with $I C_{50}$ values of $<9 \mathrm{nmol} / \mathrm{L}$ and $21 \mathrm{nmol} / \mathrm{L}$, respectively (Fig. 3b). Cell cycle analysis revealed a significant increase in the $G_{0} / G_{1}$ phase and decrease in $S$ phase distribution in cells treated with GDC-0449, $\mathrm{HH}-13$, or $\mathrm{HH}-20$ (Fig. 3c). Consistently, immunoblotting of the inhibitor-treated cells demonstrated a downregulation in protein levels of Gli1 and cyclin D1 compared to that of vehicle-treated cells (Fig. 3d). These results suggest that similar to GDC-0449, the current series of $\mathrm{HH}$ inhibitors could effectively target the $\mathrm{Hh}$ signaling pathway function leading to growth suppression via a blockade in $G_{0} / G_{1}$ cell cycle progression.
Downregulation of mTOR pathway and induction of apoptosis in inhibitor-treated cells

Intracellular mTOR pathway plays a major role in cell growth and survival. We therefore examined signaling status of mTOR complexes (mTORCs) as the potential downstream mediators of SMO-targeted growth inhibition. We found that the $\mathrm{SHH}$-induced phosphorylation of mTORC1 biomarker P-S6 (S235/236) and mTORC2 biomarker P-AKT (S473) in NIH3T3 cells were potently and profoundly inhibited by $\mathrm{HH}-13$ and $\mathrm{HH}-20$ with effective doses at $<1 \mu \mathrm{mol} / \mathrm{L}$ (Fig. 4a). For comparison, $1 \mu \mathrm{mol} / \mathrm{L}$ GDC-0449 near completely suppressed P-S6 and consistently but partially reduced $\mathrm{P}$-AKT. These results indicated that the anti-proliferative 

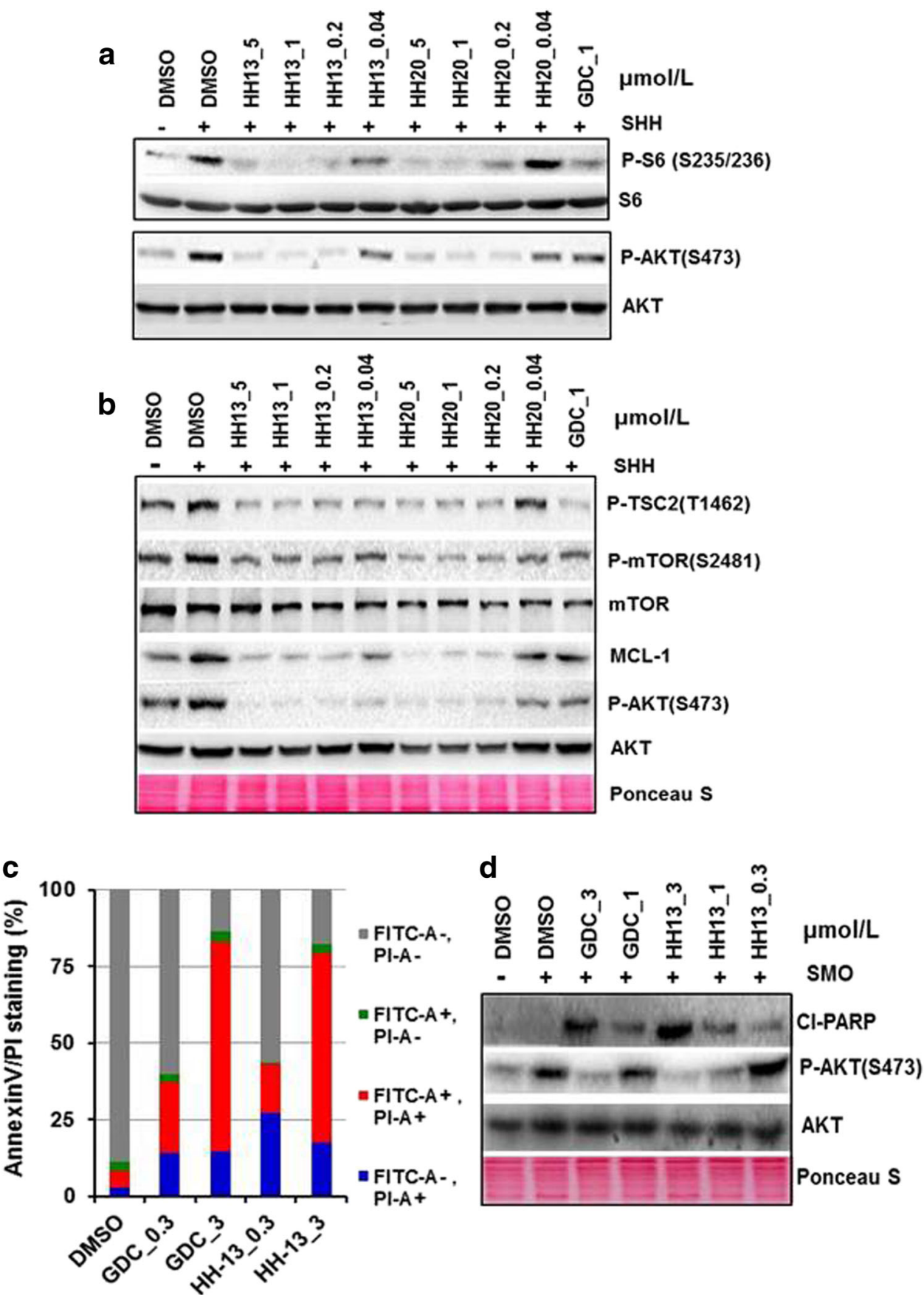

Fig. 4 Targeting of Hh pathway function leads to downregulation of mTOR/AKT activity. $\mathbf{a}$, $\mathbf{b}$ Serum-starved NIH3T3 cells were induced with $\mathrm{SHH}$ for $48 \mathrm{~h}$ without or with the indicated inhibitors. Total cell lysates were prepared and subjected to immunoblotting as indicated. c 293T cells were transfected with SMO-WT expression vector for $24 \mathrm{~h}$, treated with inhibitors for $48 \mathrm{~h}$, subjected to Annexin V-FITC/PI staining. Positive populations as analyzed by FACS are plotted. $\mathbf{d}$ Cells as in c were collected and immunoblotted

effects of the current SMO inhibitors are mediated through downregulation of mTOR activity. We examined additional mTOR readouts and signaling regulation. In cells treated with $\mathrm{HH}-13, \mathrm{HH}-$ 20, and GDC-0449, there were substantial reduction in P-TSC2 (T1462) as well as partial loss of P-mTOR (S2481) and mTOR, all of which are consistent with a diminished signaling input to mTOR network (Fig. 4b). Importantly, targeting of SMO in this setting also dramatically downregulated level of $\mathrm{MCL}-1$, an apoptosis inhibitory protein recently shown to be protected by mTORC2/AKT axis [24] (Fig. 4b). We then analyzed 293T human cells transfected with the wild-type smoothened (SMO-WT). After $48 \mathrm{~h}$ treatment, there was a dose-dependent and substantial increase of apoptosis in both the GDC-0449- and HH-13 treated cells as shown by Annexin V/PI staining (Fig. 4c) and PARP cleavage (Fig. 4d). Taken together, these results highlight a molecular suppression of mTOR network and induction of apoptotic death in SMO-targeted antitumor effects.

Blockade of the Hh paracrine signaling in tumor environment Paracrine signaling has an important role in $\mathrm{Hh} / \mathrm{SMO}$ pathway activation of various cancers. A schematic diagram shows the in vivo paracrine stimulation of stromal Hh pathway (Fig. 5a) $[25,26]$. The 
a

b
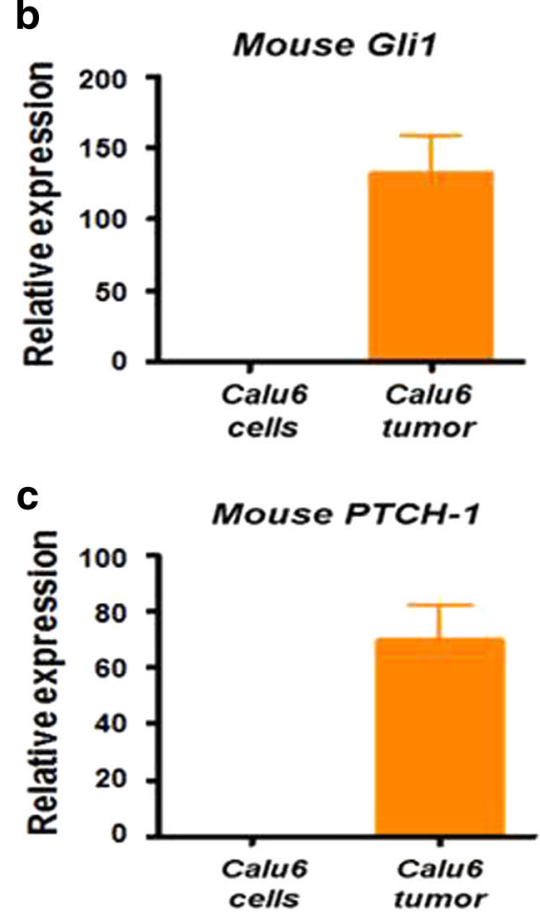

d

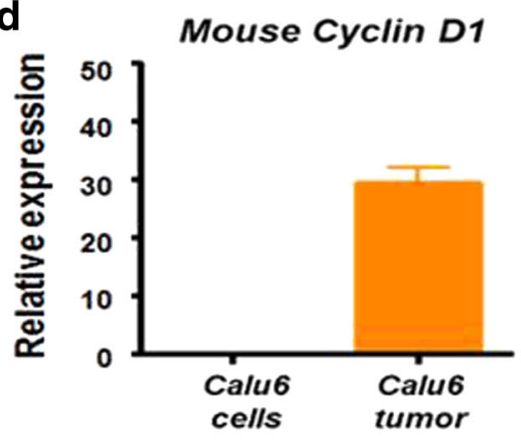

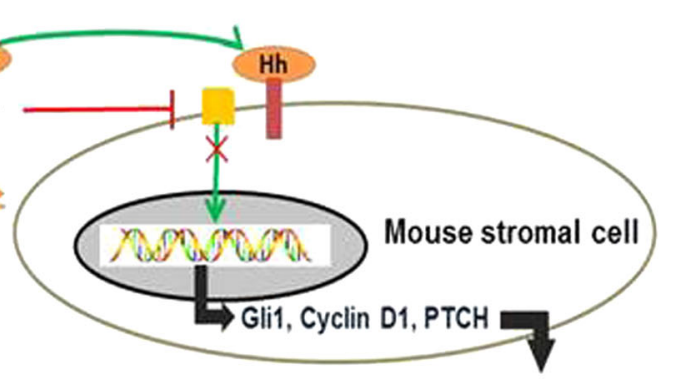

Detect mouse mRNA level
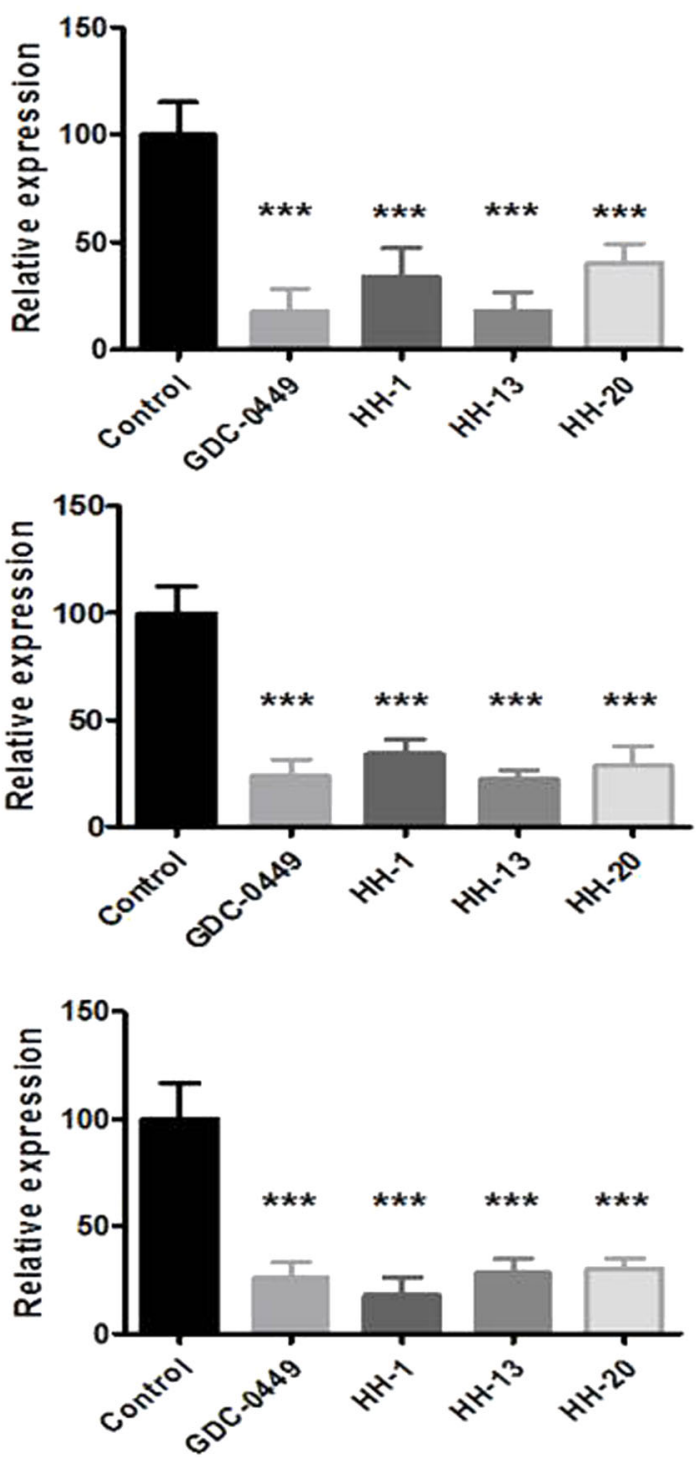

Fig. 5 New SMO inhibitors target paracrine Hh pathway in vivo. a Schematic diagram shows the in vivo paracrine stimulation of stromal Hh pathway. b-d Nude mice bearing Calu- 6 tumors $\left(\sim 400 \mathrm{~mm}^{3}\right)$ were dosed orally with $75 \mathrm{mg} / \mathrm{kg} \mathrm{GDC}-0449, \mathrm{HH}-1, \mathrm{HH}-13$, or HH-20 twice daily (bid) for a total of five doses. Tumors were collected and analyzed for stromal expression of mouse Hh pathway biomarkers using mousespecific PCR primers. Tumors were analyzed for mRNA levels of mouse Gli1 (b), mouse PTCH-1 (c) and mouse cyclin D1 (d). In RT-PCR measurements of each gene set, RNA samples of Calu- 6 cells grown in cell culture dish served as a background control for the assay (left panels). For tumor results, relative expression levels are shown (right panels). Statistical analysis (treated vs. vehicle control): ${ }^{* * *} P<0.001$

Calu-6 lung tumor in vivo mouse model could be used as an $\mathrm{Hh}$ paracrine stimulation model [27]. We observed that while no mousespecific gene expression was detected in cultured Calus- 6 cells, the in vivo tumors were associated with an extensive recruitment and activation of mouse stromal Gli1, PTCH-1, and cyclin D1 gene expression (Fig. 5b-d, left panels). Oral treatment of the Calu- 6 tumor-bearing mice with $\mathrm{HH}-1, \mathrm{HH}-13$, and $\mathrm{HH}-20(75 \mathrm{mg} / \mathrm{kg}$, bid; total five doses) each led to a highly substantial suppression of the mouse stromal Gli1, PTCH-1, and cyclin D1 $(P<0.001)$, which were comparable to that by GDC-0449 (Fig. 5b-d, right panels). These results indicate that similar to GDC-0449, the current series of inhibitors can effectively inhibit $\mathrm{Hh}$ paracrine activation in vivo. 
a

$\mathrm{Ptch}^{+/-P 53^{-/} \text {medulloblastoma }}$

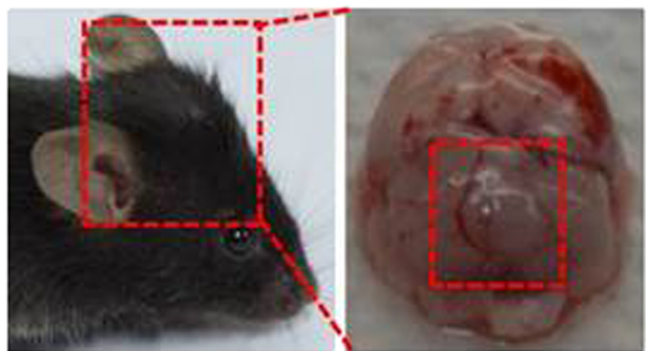

b

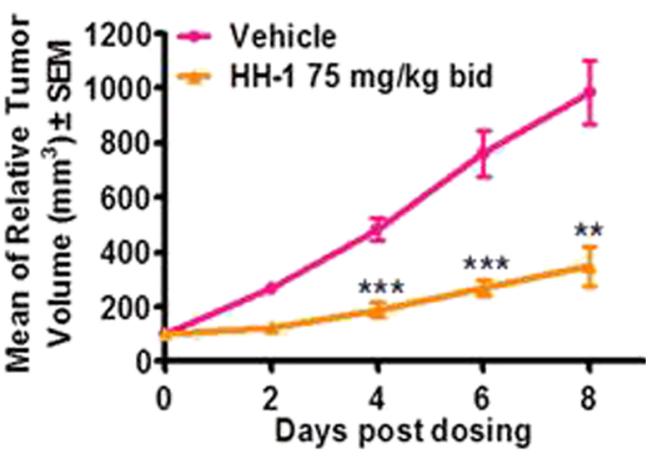

C

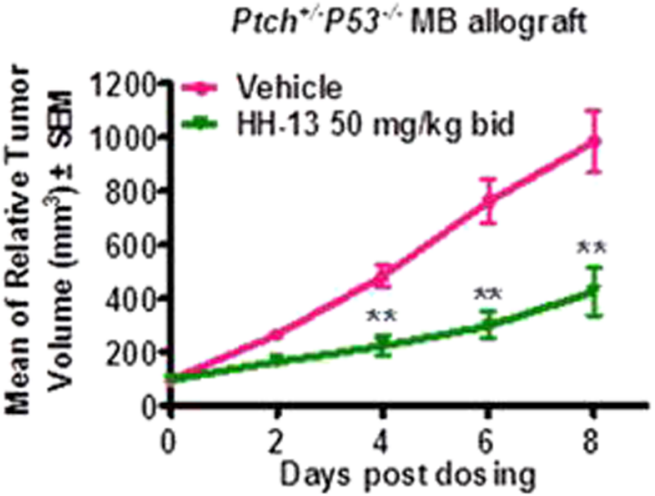

d

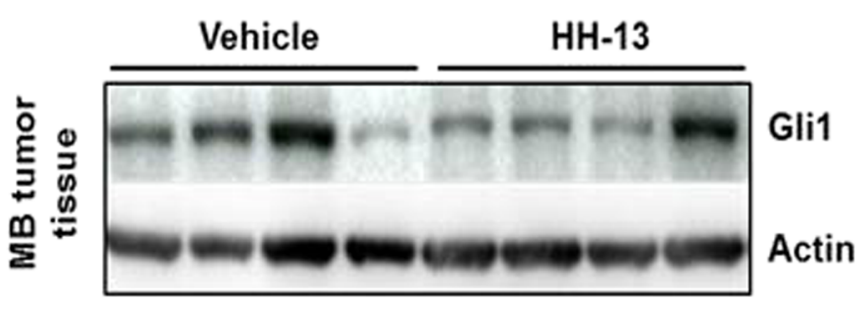

MB allograft

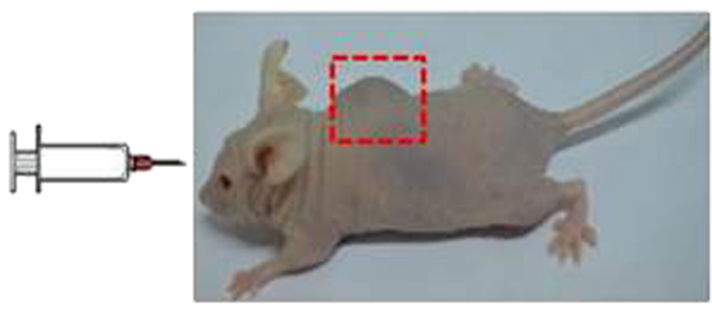

Body Weight

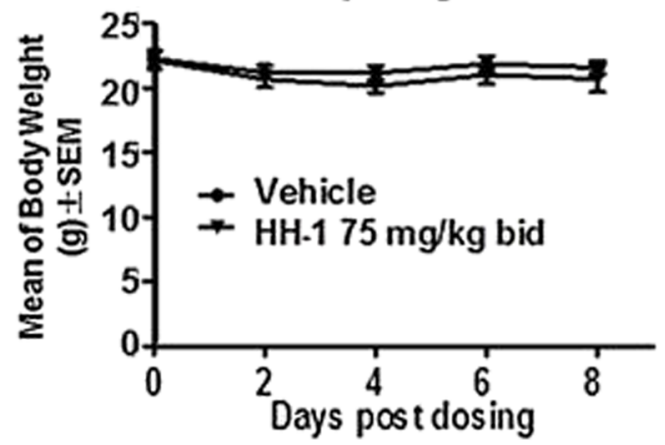

Body Weight
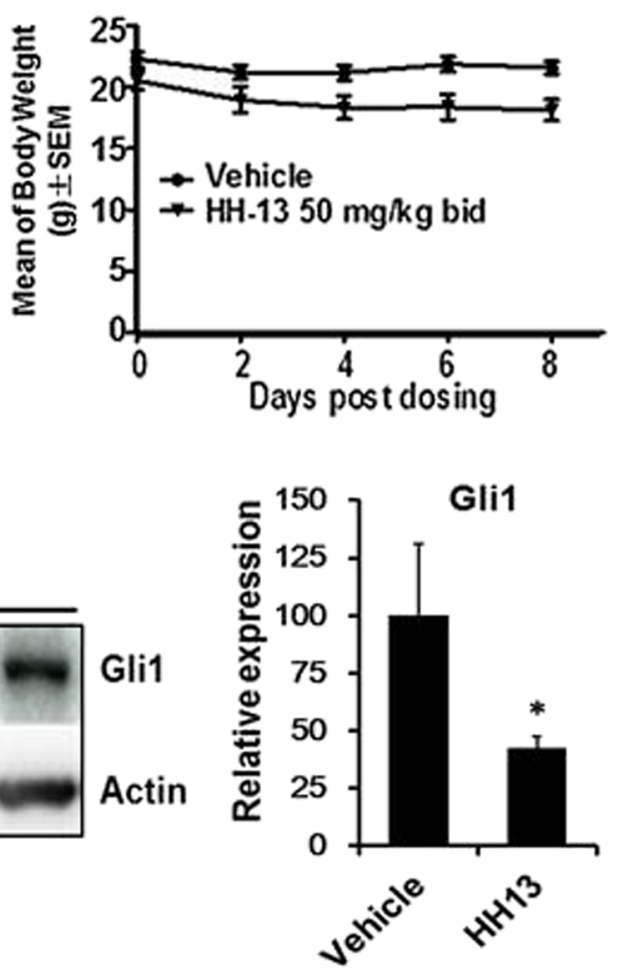

Fig. 6 Inhibition of PTCH ${ }^{+/-} / \mathrm{P} 53^{-/-}$medulloblastoma (MB) allograft tumor growth in vivo. a Mice bearing PTCH ${ }^{+/-} \mathrm{P} 53^{-/-} \mathrm{MB}^{\mathrm{brain}}$ tumors (left panel) and allograft tumors (right panel) are shown. b, c Mice bearing the staged allograft MB tumors were treated with vehicle, $75 \mathrm{mg} / \mathrm{kg}$ $\mathrm{HH}-1$ (b) or $50 \mathrm{mg} / \mathrm{kg} \mathrm{HH}-13$ (c) following a twice daily (bid) oral dosing regimen. Tumor growth curves (left panels) and body weight changes (right panels) are shown. d At the end of study in c, tumors were collected and subjected to immunoblotting (left panel). The quantified results $(n=4)$ are plotted (right panel). Statistical analysis (treated vs. vehicle control): ${ }^{*} P<0.05 ;{ }^{* *} P<0.01 ;{ }^{* * *} P<0.001$ 
a

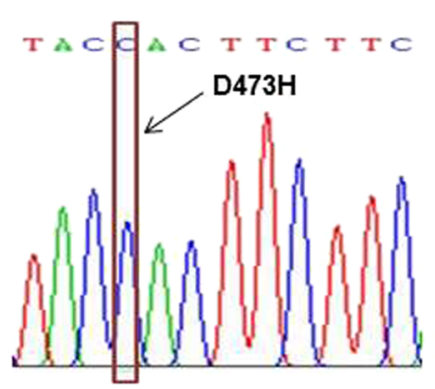

b

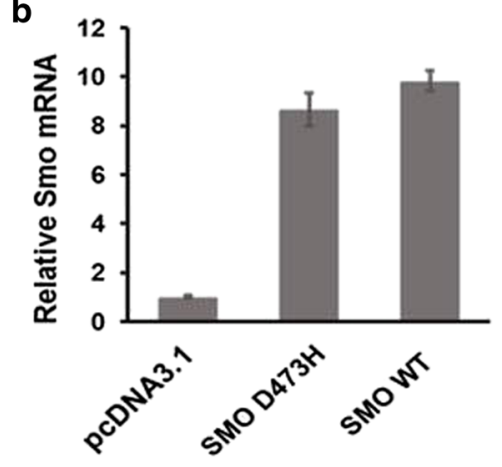

e

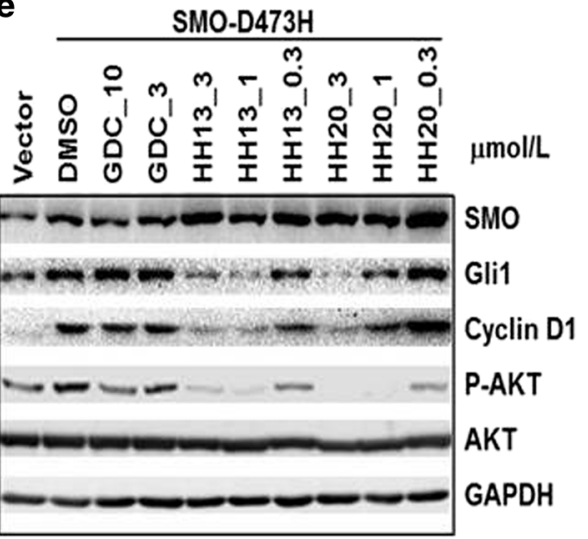

C

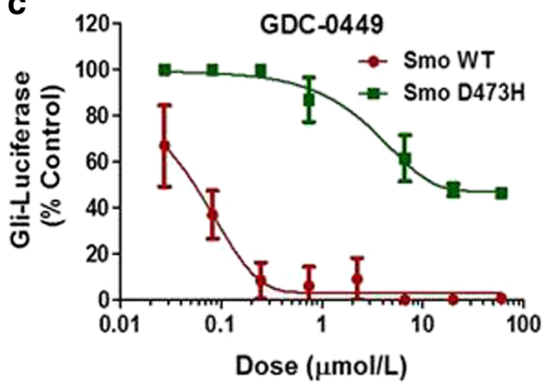

HH13
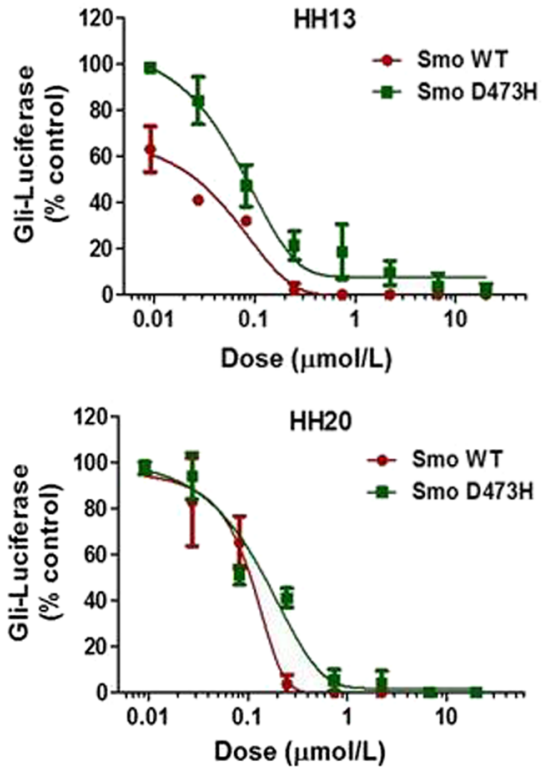

d

\begin{tabular}{c|c|c}
$I_{50}(\mu \mathrm{mol} / \mathrm{L})$ & SMO WT & SMO D473H \\
\hline $\mathrm{GDC}-0449$ & $0.076 \pm 0.003$ & $>60$ \\
\hline $\mathrm{HH}-13$ & $0.038 \pm 0.012$ & $0.086 \pm 0.022$ \\
\hline $\mathrm{HH}-20$ & $0.125 \pm 0.059$ & $0.174 \pm 0.025$ \\
\hline
\end{tabular}

Fig. $7 \mathrm{HH}-13$ and $\mathrm{HH}-20$ are effective in targeting GDC-0449-resistant SMO-D473H. a Construction of SMO-WT and SMO-D473H expression vectors. DNA sequence with the D473H point mutation is shown. b 293T cells were transfected with SMO-WT or SMO-D473H plasmids for $8 \mathrm{~h}$, collected for analysis of SMO overexpression by PCR. c, d 293T cells were transiently transfected with Gli1-luc plus SMO-WT or Gli1-luc plus SMO-D473H plasmids for $24 \mathrm{~h}$, treated with the indicated inhibitors for $48 \mathrm{~h}$. Luciferase assays were performed as described in Methods. For inhibition results, dose-response curves $(\mathbf{c})$ and $\mathrm{IC}_{50}$ values $(\mathbf{d})$ are shown. e 293T cells expressing the SMO-D473H were treated with inhibitors for $48 \mathrm{~h}$. Cells were collected and subjected to immunoblotting

Antitumor activity in $\mathrm{PTCH}^{+/-} / \mathrm{P} 53^{-/-}$medulloblastoma mouse model

There is strong evidence that nearly one third of medulloblastoma (MB) is related to the dysregulation of the Hh pathway [28] and the $\mathrm{PTCH}^{+/-} / \mathrm{P}^{2} 3^{-1-}$ spontaneous $\mathrm{MB}$ is a good experimental mouse model. [29] We established this model (Fig. 6a) and validated it using GDC-0449, which demonstrated the expected efficacy (not shown). Oral treatment of mice bearing the $M B$ allograft tumors with $75 \mathrm{mg} / \mathrm{kg} \mathrm{HH}-1$ or $50 \mathrm{mg} / \mathrm{kg} \mathrm{HH}-13$ resulted in a significant tumor growth delay $(P<0.01)$ without overt toxicity or loss of body weight (Fig. 6 b, c). Similar treatment with $50 \mathrm{mg} / \mathrm{kg} \mathrm{HH}-20$ showed a hint of efficacy $(P<0.05)$ (Figure S1B). The weaker in vivo activity of $\mathrm{HH}-20$ may in part reflect the lower bioavailability of this compound (Figure S1A). Immunoblotting analysis showed a trend for reduced Gli1 protein in inhibitortreated tumors compared to vehicle control $(P<0.05)$ (Fig. $6 \mathrm{~d}$ ). These results overall indicate that $\mathrm{HH}-1, \mathrm{HH}-13$, and $\mathrm{HH}-20$ can elicit in vivo targeting of $\mathrm{Hh}$-signaling function and the pathwaydriven tumor growth, albeit less potent than required for drug development.

$\mathrm{HH}-13$ and $\mathrm{HH}-20$ potently target GDC-0449-resistant Smoothened D473H mutation

Finally, to investigate whether the current inhibitor series could overcome acquired drug resistance to the first generation SMO inhibitors, we established the smoothened $\mathrm{D} 473 \mathrm{H}$ mutant expression construct [16] (Fig. 7a). Upon transfection into $293 \mathrm{~T}$ cells, both the SMO wide-type (SMO-WT) and SMO-D473H mutant (SMO-D473H) could be expressed with similar yields (Fig. 7b). In parallel Gli1-luc reporter assays of SMO-WT and SMOD473H, GDC-0449 potently inhibited the activation of SMO-WT $\left(\mathrm{IC}_{50}: 0.076 \mu \mathrm{mol} / \mathrm{L}\right)$ but was poorly active in the assay for SMO-D473H ( $\mathrm{IC}_{50}$ : $\left.>60 \mu \mathrm{mol} / \mathrm{L}\right)$ (Fig. $7 \mathrm{c}$, top panel). In contrast, both $\mathrm{HH}-13$ and $\mathrm{HH}-20$ retained decent inhibition potency when 
assayed against SMO-D473H, achieving $\mathrm{IC}_{50}$ values of 0.086 and $0.174 \mu \mathrm{mol} / \mathrm{L}$, respectively (Fig. 7c, d). To further confirm these results, we examined the effect on down-regulating the signaling biomarker driven by SMO-D473H. In 293T cells transfected with SMO-D473H, there was a coordinated activation in Gli1, cyclin D1, and P-AKT (Fig. 7e). Although these SMO-D473H-dependent signaling biomarkers were largely resistant to GDC-0449, they were dose dependently blocked by $\mathrm{HH}-13$ and $\mathrm{HH}-20$ with approximate $\mathrm{EC}_{50}$ values of $0.3 \mu \mathrm{mol} / \mathrm{L}$ and $1 \mu \mathrm{mol} / \mathrm{L}$, respectively (Fig. 7e). Thus, these results overall indicate that both $\mathrm{HH}-13$ and $\mathrm{HH}-20$ could effectively target the GDC-0449-resistant SMO-D473H mutation.

\section{DISCUSSION}

The FDA-approved Vismodegib/GDC-0449 and Sonidegib/LDE225 have presented a new hope for surgery unfavorable metastatic BCC patients [30, 31]. Other SMO inhibitors under development also showed positive responses in disease control $[32,33]$. These achievements have spurred a new wave of SMO inhibitor research. As part of expanded discovery efforts, we uncovered a new series of SMO inhibitors, exemplified by $\mathrm{HH}-1, \mathrm{HH}-13$, and $\mathrm{HH}-20$ that potently target the $\mathrm{Hh} / \mathrm{SMO} / \mathrm{Gli} 1$ pathway function in vitro and in vivo. Strong evidence points to the aberrant $\mathrm{Hh}$ signaling as cancer driver in advanced BCC and PTCH-deficient MB molecular type $[5,34]$. The current inhibitor series are shown to inhibit the $\mathrm{Hh}$ pathway-driven cell proliferation accompanying $\mathrm{G}_{0} / \mathrm{G}_{1}$ cell cycle blockade and reduction of the pathway target gene expression. Moreover, in the $\mathrm{Hh}$-driven $\mathrm{PTCH}^{+/-} \mathrm{MB}$ in vivo model, both $\mathrm{HH}-1$ and $\mathrm{HH}-13$ attenuated allograft tumor growth, which correlated with the downregulation of pathway related gene expression.

As SMO inhibitors display profound anti-proliferation capacity in the Hh-driven NIH3T3 model and MB allografts, some studies observed no direct correlation between downregulation of pathway genes and in vitro anti-proliferative response in certain cancer cells [35]. Emerging evidence now supports a role for paracrine $\mathrm{Hh}$ signaling activation in tumorigenesis [35, 36]. Indeed, our work confirmed the presence of lung tumor cell $\mathrm{Hh}$-induced paracrine stromal activation in mice, in which the tumor-induced stromal expression of Gli1, PTCH-1, and cyclin D1 were all blocked by orally administered GDC-0449 and current series of SMO inhibitors.

Downregulation of mTOR/AKT signaling function has an important role in SMO inhibitor-mediated growth suppression. The relationship was also observed in ovarian cancer cells in which depletion of AKT gene could partially reverse Gli1-induced EMT [37]. In chronic lymphocytic leukemia cell line, a Gli1 inhibitor GAN61 inhibited AKT phosphorylation [38]. In our studies, both GDC-0449 and current series of inhibitors reduced P-TSC2 (T1462) resulting in higher suppressive activity toward mTORC1. Likewise, both inhibitor classes targeted mTORC2 substrate P-AKT (S473) and its secondary readout MCL-1 [24]. Because MCL-1 is a wellcharacterized inhibitor of apoptosis, suppression of MCL-1 in this setting likely contributed to the efficacy of SMO inhibitors. Although the exact mechanism on how $\mathrm{Hh} / \mathrm{SMO}$ signals to TSC2/mTORC1 or mTORC2/AKT remains to be elucidated, the results of current work and previous reports highlight a critical role for mTOR network in the Hh pathway-dependent cancer cell growth and tumorigenesis [38-41].

Acquired drug resistance and tumor relapse are weaknesses of the first generation SMO-targeted drugs. Our inhibitors are intended to overcome the clinically prevalent smoothened mutation SMO-D473H, which renders GDC-0449 and LDE225 binding inefficient and clinical resistance. We have shown that in contrast to GDC-0449, both $\mathrm{HH}-13$ and $\mathrm{HH}-20$ elicited potent inhibition of SMO-D473H. This conclusion is based on their activity in specific suppression of SMO-D473H-driven Gli1-reporter signal and the blockade of SMO-D473H-driven cellular pathway biomarkers. Additional support for specific SMO-targeting by these compounds came from their structure and activity relationship (SAR) profile. In this SAR process, when we varied substituent on the pyridine ring and amide benzene ring, their activity behaviors were very similar to the SAR profile for GDC-0449 [42]. A major deficiency of our study is the lack of direct binding data on these inhibitors to purified SMO proteins. Future studies are required to elucidate the inhibitor binding mode to both the naïve and drugresistant SMO variants. Collectively, the current inhibitors may present an opportunity for medicinal chemistry optimization on pharmaceutical property towards the development of new generation SMO inhibitor therapy.

\section{ACKNOWLEDGEMENTS}

This work was supported by a startup grant from Fudan University (EZF301002) and National Natural Science Foundation of China (81273367). We thank Fudan University School of Pharmacy Animal Facility and Instrument Center for excellent technical support.

\section{AUTHOR CONTRIBUTIONS}

Conception and design: H.L., K.Y. Development of methodology: H.Z., Q.L., K.Y. Acquisition of data: H.Z., Q.L., X.Z. Analysis and interpretation of data: H.Z., Q.L., X.Z. Writing, review, and/or revision of the manuscript: Q.L., H.L., K.Y. Administrative, technical, or material support: H.L., K.Y. Study supervision: K.Y.

\section{ADDITIONAL INFORMATION}

The online version of this article (https://doi.org/10.1038/s41401-018-0019-5) contains supplementary material, which is available to authorized users.

Competing interests: The authors declare no competing interests.

\section{REFERENCES}

1. Ishibashi M, Mcmahon AP. A sonic hedgehog-dependent signaling relay regulates growth of diencephalic and mesencephalic primordia in the early mouse embryo. Development. 2002;129:4807-19.

2. Pasca DMM, Hebrok M. Hedgehog signalling in cancer formation and maintenance. Nat Rev Cancer. 2003;3:903-11.

3. Amakye D, Jagani Z, Dorsch M. Unraveling the therapeutic potential of the Hedgehog pathway in cancer. Nat Med. 2013;19:1410-22.

4. Yang $L$, Xie GQ, Xie J. Activation of the hedgehog-signaling pathway in human cancer and the clinical implications. Oncogene. 2010;29:469-81.

5. Teglund S, Toftgard R. Hedgehog beyond medulloblastoma and basal-cell carcinoma. Biochim Et Biophys Acta. 2010;1805:181-208.

6. Harris LG, Samant RS, Shevde LA. Hedgehog signaling: networking to nurture a pro-malignant tumor microenvironment. Mol Cancer Res. 2011;9:1165-74.

7. Ehtesham M, Sarangi A, Valadez JG, Chanthaphaychith S, Becher MW, Abel TW, et al. Ligand-dependent activation of the hedgehog pathway in glioma progenitor cells. Oncogene. 2007;26:5752-61.

8. Athar M, Li C, Tang X, Chi S, Zhang X, Kim AL, et al. Inhibition ofsmoothened signaling prevents ultraviolet $\mathrm{B}$-induced basal cell carcinomas through regulation ofFas expression and apoptosis. Cancer Res. 2004;64:7545-52.

9. Dummer R, Guminski A, Gutzmer R, Dirix L, Lewis KD, Combemale P, et al. The 12month analysis from basal cell carcinoma outcomes with LDE225 treatment (BOLT): a phase II, randomized, double-blind study of sonidegib in patients with advanced basal cell carcinoma. J Am Acad Dermatol. 2016;75:113-25.

10. Von Hoff DD, Lorusso PM, Rudin CM, Reddy JC, Yauch RL, Tibes R, et al. Inhibition of the hedgehog pathway in advanced basal-cell carcinoma. New Engl J Med. 2009;361:1164-72.

11. Watkins DN, Berman DM, Burkholder SG, Wang B, Beachy PA, Baylin SB. Hedgehog signalling within airway epithelial progenitors and in small-cell lung cancer. Nature. 2003;422:313-7.

12. Yauch RL, Dijkgraaf GJP, Alicke B, Januario T, Ahn CP, Holcomb $T$, et al. Smoothened mutation confers resistance to a hedgehog pathway inhibitor in medulloblastoma. Science. 2009:326:572-4.

13. Sharpe HJ, Pau G, Dijkgraaf GJ, Bassetseguin N, Modrusan Z, Januario T, et al. Genomic analysis of smoothened inhibitor resistance in basal cell carcinoma. Cancer Cell. 2015;27:327-41. 
14. Danial C, Sarin KY, Oro AE, Chang AL. An investigator-initiated open-label trial of sonidegib in advanced basal cell carcinoma patients resistant to vismodegib. Clin Cancer Res. 2016;22:1325-9.

15. Sharpe HJ, Pau G, Dijkgraaf GJ, et al. Genomic analysis ofsmoothened inhibitor resistance in basal cell carcinoma. J Cancer Cell. 2015;27:327-41.

16. Atwood SX, Sarin KY, Whitson RJ, Li JR, Kim G, Rezaee M, et al. Smoothened variants explain the majority of drug resistance in basal cell carcinoma. J Cancer Cell. 2015;27:342-53.

17. Ishii T, Shimizu Y, Nakashima K, Kondo S, Ogawa K, Sasaki S, et al. Inhibition mechanism exploration of investigational drug tak-441 as inhibitor against vismodegib-resistant smoothened mutant. Eur J Pharmacol. 2014;723:305-13.

18. Peukert S, He F, Dai M, Zhang R, Sun Y, Miller-Moslin K, et al. Cover picture: discovery of nvp-leq506, a second-generation inhibitor of smoothened (chemmedchem 8/2013). ChemMedChem. 2013;8:1261.

19. Lee MJ, Hatton BA, Villavicencio EH, Khanna PC, Friedman SD, Ditzler $S$, et al. Hedgehog pathway inhibitor saridegib (ipi-926) increases lifespan in a mouse medulloblastoma model. Proc Natl Acad Sci USA. 2012;109:7859-64.

20. Lang, H., Yu, K., \& Zhao, H. Benzimidazole compound with antitumour activity as well as preparation method and application thereof. Patent Application CN201310139335.

21. Lang, H., Yu, K., \& Zhao, H. Benzimidazole amide compound as well as preparation method and application thereof. Patent Application CN201310186206.

22. Koo J, Yue P, Deng X, Khuri FR, Sun SY. mTOR complex 2 stabilizes Mcl-1 protein by suppressing its glycogen synthase kinase 3-dependent and SCF-FBXW7mediated degradation. Mol Cell Biol. 2015;35:2344-55.

23. Li X, Wang $Z$, Ma $Q, X u Q$, Liu $H$, Duan $W$, et al. Sonic hedgehog paracrine signaling activates stromal cells to promote perineural invasion in pancreatic cancer. Clin Cancer Res. 2014;20:4326-38.

24. Lubik AA, Nouri M, Truong S, Ghaffari M, Adomat HH, Corey E, et al. Paracrine sonic hedgehog signaling contributes significantly to acquired steroidogenesis in the prostate tumor microenvironment. Int J Cancer. 2017;140:358-69.

25. Robarge KD, Brunton SA, Castanedo GM, Cui Y, Dina MS, Goldsmith R, et al. GDC0449-a potent inhibitor of the hedgehog pathway. Bioorg Med Chem Lett. 2009;19:5576-81.

26. Kool M, Korshunov A, Remke $M$, Jones DT, Schlanstein $M$, Northcott $P A$, et al. Molecular subgroups of medulloblastoma: an international metaanalysis of transcriptome, genetic aberrations, and clinical data of WNT, SHH, Group 3, and group 4 medulloblastomas. Acta Neuropathol. 2012;123:473-84.

27. Romer JT, Kimura H, Magdaleno S, Sasai K, Fuller C, Baines $H$, et al. Suppression of the Shh pathway using a small molecule inhibitor eliminates medulloblastoma in Ptc1(+/-)p53(-/-) mice. Cancer Cell. 2004;6:229-40.

28. Dummer R, Guminski A, Gutzmer R, Dirix L, Lewis K, Combemale $P$, et al. LBA33 randomized, double-blind study of sonidegib (LDE225) in patients (PTS) with advanced basal cell carcinoma (BCC). Ann Oncol. 2014;25:1-41.
29. Chang ALS, Solomon JA, Hainsworth JD, Goldberg L, McKenna E, Day B-M, et al Expanded access study of patients with advanced basal cell carcinoma treated with the hedgehog pathway inhibitor, vismodegib. J Am Acad Dermatol. 2014;70:60-9.

30. Sasaki K, Gotlib JR, Mesa RA, Newberry KJ, Ravandi F, Cortes JE, et al. Phase II evaluation of IPI-926, an oral hedgehog inhibitor, in patients with myelofibrosis. Leuk Lymphoma. 2015;56:2092-7.

31. Wagner AJ, Messersmith WA, Shaik MN, Li S, Zheng X, McLachlan KR, Cesari R, Courtney R, Levin WJ, El-Khoueiry AB. Aphase IstudyofPF-04449913,an oralhedgehog inhibitor,in patients with advanced solid tumors. Clin Cancer Res. 2015;21:1044-51.

32. Remke M, Hielscher $T$, Northcott PA, Witt $H$, Ryzhova M, Wittmann A, et al. Adult medulloblastoma comprises three major molecular variants. J Clin Oncol. 2011;29:2717-23.

33. Yauch RL, Gould SE, Scales SJ, Tang $T$, Tian $H, A h n C P$, et al. A paracrine requirement for hedgehog signalling in cancer. Nature. 2008;455:406-10.

34. Ingram WJ, Wicking CA, Grimmond SM, Forrest AR, Wainwright BJ. Novel genes regulated by sonic hedgehog in pluripotent mesenchymal cells. Oncogene. 2002;21:8196-205.

35. Ke Z, Caiping S, Qing Z, Xiaojing W. Sonic hedgehog-Gli1 signals promote epithelial-mesenchymal transition in ovarian cancer by mediating PI3K/AKT pathway. Med Oncol. 2015;32:368.

36. Kern D, Regl G, Hofbauer SW, Altenhofer P, Achatz G, Dlugosz A, et al. Hedgehog/ $\mathrm{GLI}$ and $\mathrm{PI} 3 \mathrm{~K}$ signaling in the initiation and maintenance of chronic lymphocytic leukemia. Oncogene. 2015;34:5341-51.

37. Buonamici S, Williams J, Morrissey M, Wang A, Guo R, Vattay A, et al. Interfering with resistance to smoothened antagonists by inhibition of the $\mathrm{PI} 3 \mathrm{~K}$ pathway in medulloblastoma. Sci Transl Med. 2010;2:51ra70.

38. Metcalfe C, Alicke B, Crow A, Lamoureux M, Dijkgraaf GJ, Peale F, et al. PTEN loss mitigates the response of medulloblastoma to hedgehog pathway inhibition. Cancer Res. 2013;73:7034-42.

39. Sharma N, Nanta R, Sharma J, Gunewardena S, Singh KP, Shankar S, et al. PI3K/ AKT/mTOR and sonic hedgehog pathways cooperate together to inhibit human pancreatic cancer stem cell characteristics and tumor growth. Oncotarget. 2015;6:32039-60.

40. Dijkgraaf GJ, Alicke B, Weinmann L, Januario T, West K, Modrusan Z, et al. Small molecule inhibition of GDC-0449 refractory smoothened mutants and downstream mechanisms of drug resistance. Cancer Res. 2011;71:435-44.

41. Yu K, Toral-barza L, Shi C, Zhang WG, Lucas J, Shor B, et al. Biochemical, cellular, and in vivo activity of novel ATP-competitive and selective inhibitors of the mammalian target of rapamycin. Cancer Res. 2009;69:6232-40.

42. Wetmore $C$, Eberhart DE, Curran T. Loss of p53 but not ARF accelerates medulloblastoma in mice heterozygous for patched. Cancer Res. 2001;61:513-6. 